\title{
Effect of Ginger as Anti-Inflammatory Agent on Serum Nitric Oxide, Tumor Necrotic Factor $\alpha$ (TNF- $\alpha$ ) and Interleukin 4 (IL-4) in Albino Rats with Carrageenan Induced Paw Edema
}

\section{Sameh S Gad* \\ Department of Pharmacology and Toxicology, Faculty of Pharmacy, MSA University, Cairo, Egypt}

*Corresponding author: Sameh Shaban Ali Gad, Department of Pharmacology and Toxicology, Faculty of Pharmacy, MSA University, Cairo, Egypt, Tel: 01207355765; Email: sameh.shaaban@msa.eun.eg

\section{Research Article}

Volume 2 Issue 8

Received Date: June 20, 2018

Published Date: July 09, 2018

\section{Abstract}

Inflammation is a normal response of living tissues to injury. Inflammation is a general term that indicates the local accumulation of fluid, white blood cells, and plasma proteins. Inflammation is initiated by infection, physical injury, or some local immune response. It is the normal response from the body to protect tissue and promote recovery. Inflammation is a complex process performed through the body due to many internal and external factors, in order to achieve the best control of inflammatory diseases it is mandatory to see different approaches. Using natural products is a very good example. The present study represents a comparative study with the potency of Ginger against standard ordinary Indomethacin. 4 groups of animals were used each consist of 6 animals. Representing normal group, positive group, standard group (Indomethacin) and treated group (ginger). In the Fourth group (Treated group) pre-injection of Ginger (400 mg/kg; I.P.) 1 hour prior to carrageenan injection resulted in significant decrease in the blood serum contents of (TNF- $\alpha$ ) to $40.9 \mathrm{Pg} / \mathrm{ml}$ and also result in significant decrease in Nitric Oxide (NO) value to $35.7 \mu \mathrm{mol} / \mathrm{g}$ tissue. This study has shown that ginger proved a significant anti-oedematogenic and anti-inflammatory activity on hind paw edema induced by carrageenan.

Keywords: Rat Hind Paw; Ginger; Indomethacin

\section{Introduction}

\section{Inflammation}

Inflammation definition: Simply inflammation is a normal response of living tissues to injury. Inflammation is a general term that indicates the local accumulation of fluid, white blood cells, and plasma proteins.
Inflammation is initiated by infection, physical injury, or some local immune response. It is the normal response from the body to protect tissue and promote recovery. Inflammation is a complex process performed through the body due to many internal and external factors. This complex process occurs if injury takes place or any other factors that can cause inflammation [1-3]. 
The main mechanisms of inflammation are based on two functions of limit the tissue damage and promote repairmen. Inflammation is normal response of the living tissue to harmful stimuli, injury or any infection (bacteria or Virus) [1-7].

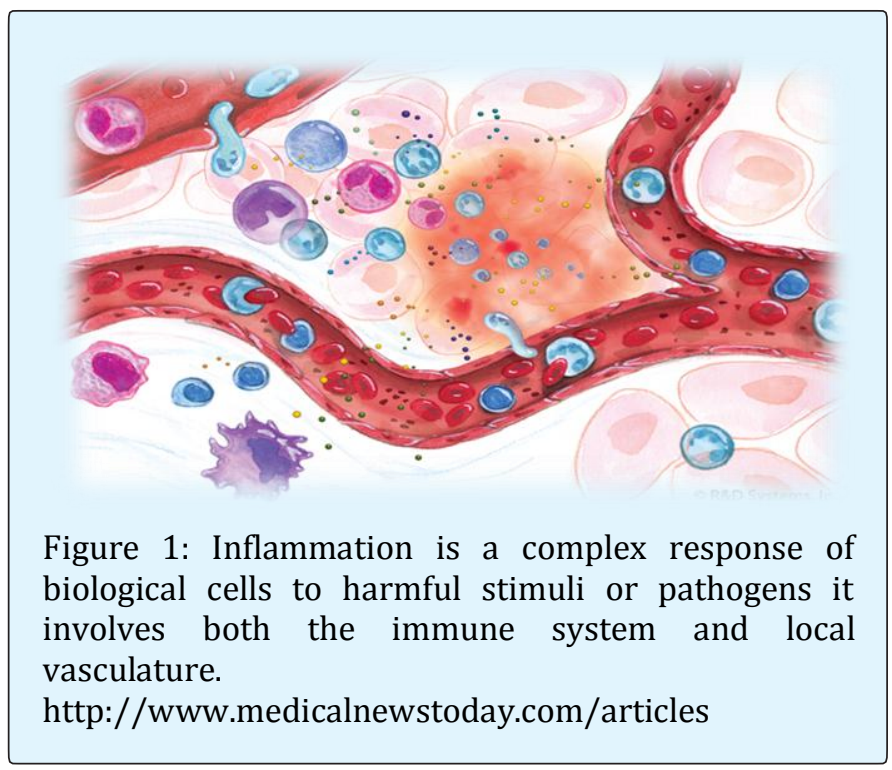

These harmful stimuli include damaged cell, pathogens, or irritants the body responds by

\section{Virology \& Immunology Journal}

inflammation of the tissue so inflammation is a normal response from the living tissues. It prepares the tissue for further healing and repairs [2].

\section{Signs and Symptoms}

Local manifestations: There is a series of events, by which the body respond to the injury of vascularised tissue this series of events is collectively called inflammation and repair. Ultimate goal is to replace injured tissue and promote healing [4]. Visual observation of the tissue that has inflammation is characterized by five cardinal signs [3-12]. These five cardinal signs include redness (rubor), heat (calor; only applicable to the body' extremities), swelling, Pain (dolor), loss of function (functio laesa) and Tenderness that can differentiate between inflammation swelling and tumor [12].

Inflammation has a beneficial effect by providing defense against infection invaders [2-5]. Also inflammation may become unchecked and dangerous due to pathogenesis of the chronic diseases. The mechanism of inflammation may be described by the main mechanism which state that the cell that on the cell membrane of the cell that has inflammation causes the lysosomal enzymes release and libration of arachidonic acid and other eicosanoids are produced [12-17].

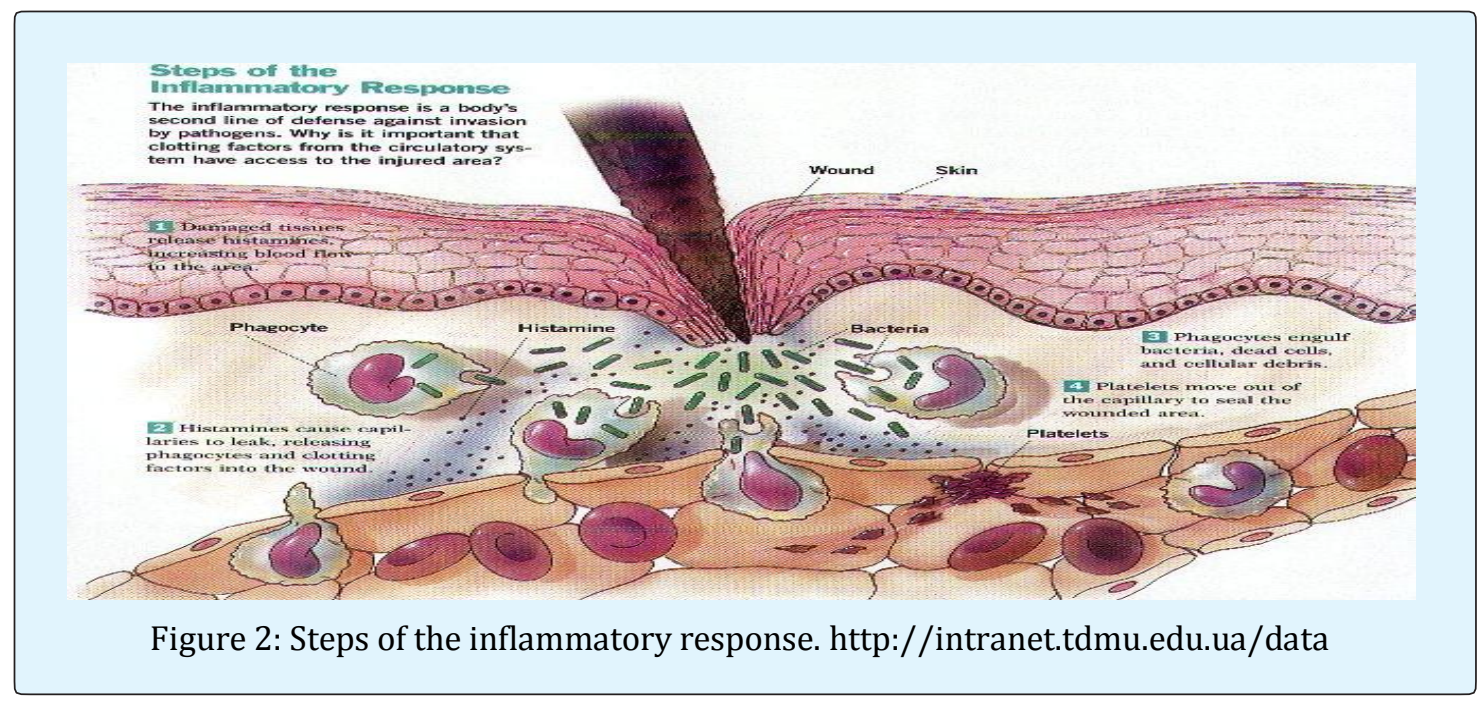

Systemic manifestations: Inflammation may be acute sub-acute and chronic that this can describe that inflammation occur at three different phases. In the first phase there is increase in vessels permeability resulting in discharge and leakage of fluid from the blood into the interstitial space, the second phase comprises of infiltration of leukocytes from the blood into the tissue and the third phase consist of formation of granuloma and then tissue repairment take place [6]. 


\section{Virology \& Immunology Journal}

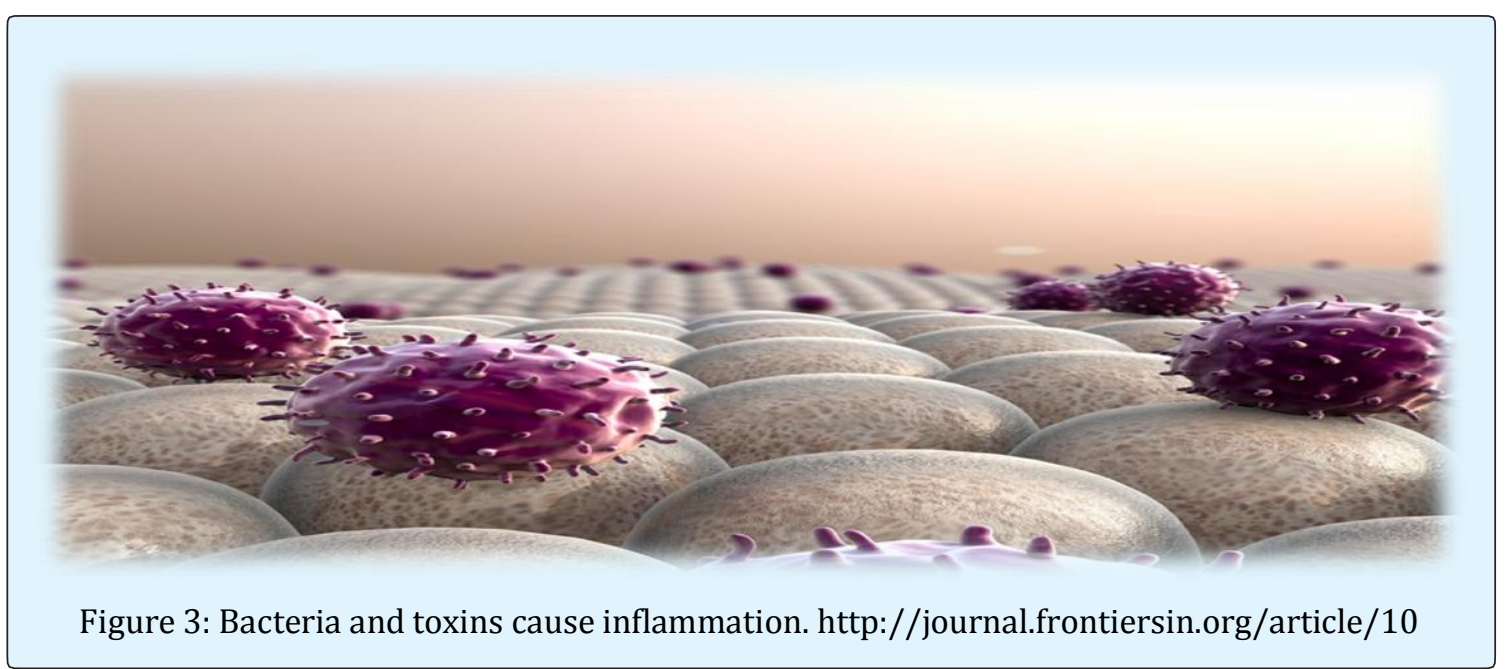

Inflammation is a complex response. There are circulatory changes in the inflammatory response these changes involve changes in permeability of the walls of vessels, white blood cells response and Release of different soluble mediators these circulatory changes also known as hemodynamic changes. It is the first response from the body to injury or mechanical stimulus which causes stimulation of the nerves that transmit the signals to the cells of smooth muscles that found in precapillary arterioles [18-31].

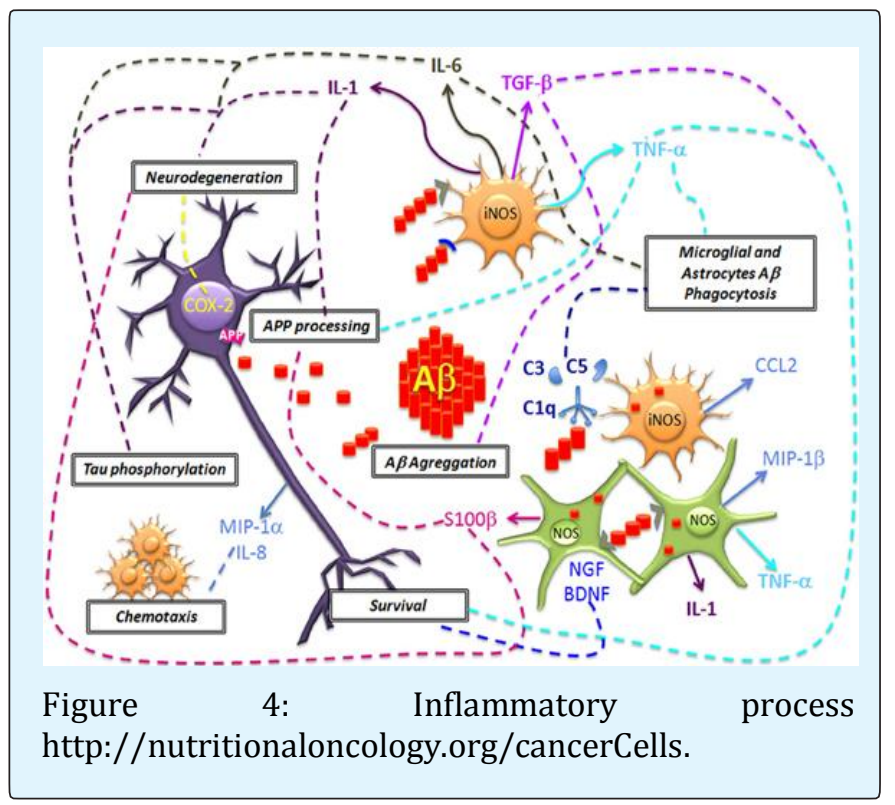

The cells in smooth muscles act as sphincters, which can regulate the blood inflow into the capillaries. Smooth muscle relaxation then allows blood to rush into the capillaries which then causes edema, erythema, heat and swelling [7] (Figure 5).

The arterioles then respond to the injury by vasoconstriction this is the first response of the arterioles and it occur a few seconds in duration this response is rapidly followed by vasodilatation flooding the capillary network with arterial blood therefore, blood influx into the area dilates capillaries (endothelial cells \& basement membrane [5-14].

Inflammation is a general term that indicates the local accumulation of fluid, white blood cells, and plasma proteins. Inflammation is initiated by infection, physical injury, or some local immune response. It is the normal response from the body to protect tissue and promote recovery. Inflammation is a complex process performed through the body due to many internal and external factors. This complex process occurs if injury takes place or any other factors that can cause inflammation [1-3].

Inflammation is a protective phenomena and a response that occurs if an injury takes place due to some internal and external factors.

The main bases of inflammation are based on two functions of limiting damage and promoting repairment of tissues. Although inflammation is beneficial in providing defense against infection invaders, it may become unchecked in case of pathogenesis of chronic inflammatory disease. The main mechanism of inflammation is that the cell related with inflammation on cell membrane to cause the release of lysosomal enzyme arachidonic acid and various eicosanoids are produced. Inflammation may be acute sub-acute and chronic occurs 


\section{Virology \& Immunology Journal}

in three different phases. The first phase consist of increase in vascular permeability resulting in secretion of fluid from the blood into the interstitial space, the second phase comprises of leukocytes infiltration from the blood into the tissue and the third phase formation of granuloma and tissue repairment take place.

Tissue injury or infection can trigger the acute inflammatory response during blood components coordination delivery. Leukocytes and plasma to the site of infection or injury [27]. Inflammation may be acute sub-acute and chronic occurs in three different phases. The first phase mainly cause increase in permeability of vessels resulting in discharge and leakage of fluid from the blood into the interstitial space, the second phase comprises of infiltration of leukocytes from the blood into the tissue and the third phase consist of formation of granuloma and then tissue repairment take place [6]. Microbial infection (especially bacterial infection) can be characterized best by this response, in which the innate immune receptors can trigger this response [15-22] (Figure 3).

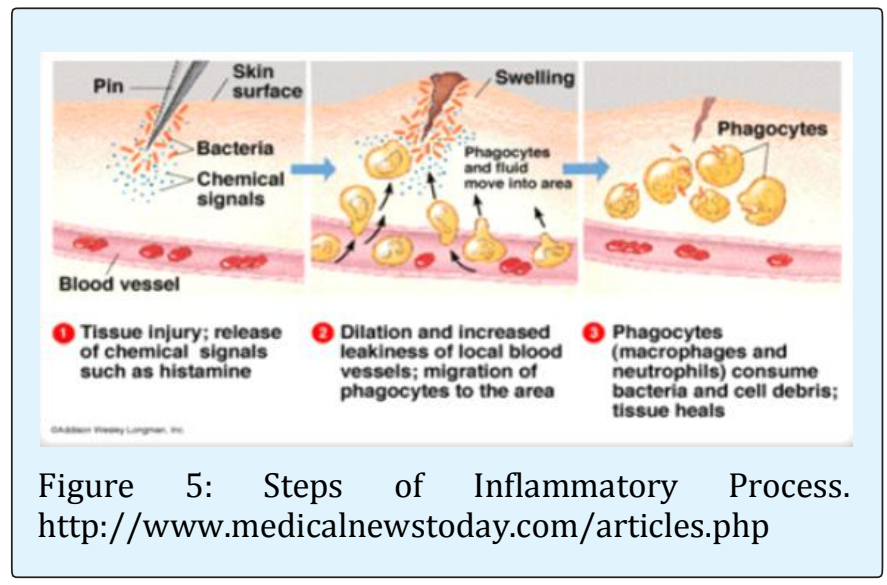

Inflammation helps in protection, by enclosing and isolating the injury. Then organisms and inactive toxins are invaded and destroyed. Consequently, healing and repair occur. Under ideal conditions the source of the tissue injury is eliminated, the inflammatory response resolves and normal tissue architecture and physiologic functions are restored. The nature of the acute inflammatory reaction is deep and the affected area is walled-off by the collection of inflammatory cells, this process results in destruction of tissue by products of polymorphonuclear leucocytes and formation of an abscess. Failure to eliminate the pathologic insult results in persistence of the inflammatory reaction. Chronic inflammation often leads to scar formation [31].
Peracute Inflammation: Definition: very acute. Usually it's caused by a potent stimulus. Commonly the animal has no time to respond morphologically to a disease process. Less common than acute disease processes [12].

Inflammation is considered one of the most dangerous monsters in our time. Many people think that inflammation is a normal serious disease such as lung cancer, respiratory tract disease. This phenomena spread due to un-educated people. This result due to absence of media \& ministry of public health role in the community to guide people how to prevent and treat inflammation by some information about inflammation [12].

Inflammation is a response from damaged tissues and cells. This process is considered as a part of healing operations but sometimes anti -bodies attack health cells and cause inflammation. People who are more susceptible for inflammation are smokers, children, elders \& obesity. Traditional treatment for inflammation is category as non -steroidal anti-inflammatory drugs and steroids but these groups have many serious with long term use.

Now all health organization undergoing to discover a new ingredient to treat inflammation instead of previous groups. Examples of natural product that can be used as inflammatory are ganger, garlic. Recent approved search approve that ginger has antioxidant and antiinflammatory properties and has no side effects so it's better for us to move to natural product rather than other pharmaceutical agents. In this study we aim at investigating the possible anti-inflammatory effect of ginger and prove that ganger has prophylaxis and antiinflammatory properties [17-20].

Neutrophils become activated when they reach the afflicted tissue site, the activation of neutrophils is done either through the actions of cytokines which is secreted by cells of tissue-resident or by direct contact with pathogens [28-31].

The neutrophils start to produce and release toxic contents of their granules by which the neutrophils can kill the foreign agents that invading the tissue [4-7]. These toxic substances that are produced by neutrophils include reactive oxygen species (ROS) and reactive nitrogen species, proteinase 3, cathepsin $G$ and elastase [7]. These highly potent effectors do not discriminate between microbial and host targets, so collateral damage to host tissues is unavoidable [13-15]. 
In acute inflammatory response there is elimination of the infectious agents which then followed by repair and resolution phase which is mainly mediated by recruited macrophages and tissue-resident [23-30]. Proinflammatory prostaglandins then cause the switch in mediatore of lipids mediators to the lipoxins. Lipoxins are inflammatory agents and is important for the transition from inflammation to resolution [15].

Phagocytosis: WBCs phagocyte bacteria and other debris and cause pus formation. WBCs send a chemical signal to brain for adjusting body thermostat therefore temperature elevates suddenly [31].

Inflammation helps in protection, by enclosing and isolating the injury. Then organisms and inactive toxins are invaded and destroyed. Consequently, healing and repair occur. Under ideal conditions the source of the tissue injury is eliminated, the inflammatory response resolves and normal tissue architecture and physiologic functions are restored. The nature of the acute inflammatory reaction is deep and the affected area is walled-off by the collection of inflammatory cells, this process results in destruction of tissue by products of polymorphonuclear leucocytes and formation of an abscess. Failure to eliminate the pathologic insult results in persistence of the inflammatory reaction. Chronic inflammation often leads to scar formation [19].

\section{Virology \& Immunology Journal}

Peracute inflammation: Definition: very acute. Usually it's caused by a potent stimulus. Commonly the animal has no time to respond morphologically to a disease process. Less common than acute disease processes [1519].

Acute inflammation: Definition: having a short and relatively severe progress. Time: It begins within four to six hours and can last for three to five days. Vascular Involvement: Active hyperemia and edema (due to endothelial damage-lymphatic and small blood vessels), Occasional fibrin thrombi within vessels [13].

Inflammatory cells: Leukocyte infiltration is variable. In general neutrophils usually predominate, but sometimes-mononuclear cells (lymphocytes and plasma cells) can also be present [15].

Clinical Signs: Most associated to the vascular changes: warm, red, swollen, painful, loss of function [19].

It is not clear how knowledge can be applicable on inflammation which caused by infection to other inflammation types. In fact, although inflammation that induced by infection is vital and important, it may be a special case [19]. Systemic chronic inflammation mechanisms are poor to understood, but it is clear that the transition from acute to chronic inflammation do not follow the classic pattern [3-11].

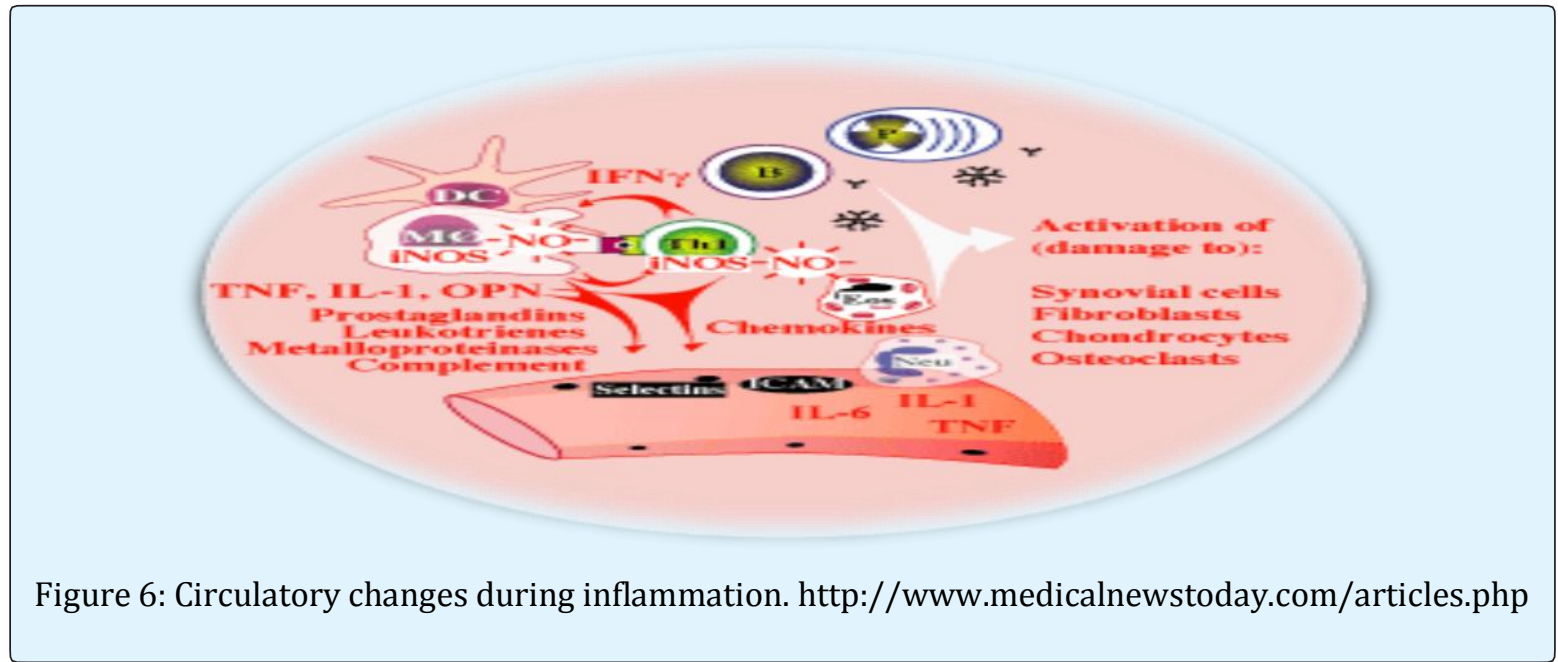

\section{Inflammatory Diseases}

There are many diseases that can be caused by inflammation that's why a list of inflammatory diseases would run to over 100 diseases. Each disease has high levels of inflammation. Inflammatory diseases include Alzheimer's disease, ankylosing spondylitis, arthritis (osteoarthritis, rheumatoid arthritis (RA), psoriatic 


\section{Virology \& Immunology Journal}

arthritis), asthma, atherosclerosis, Crohn's disease, colitis, dermatitis, diverticulitis, fibromyalgia, hepatitis, irritable bowel syndrome (IBS), systemic lupus erythematous (SLE), nephritis, Parkinson's disease and ulcerative colitis [19-27].

Rheumatoid arthritis can affect any joint in the body and often occurs in more than one joint and. People have rheumatoid arthritis feel tired and sick, and they may get fevers. The disease has mild and moderate forms people have this disease sometimes feel better and sometimes feel worse. Other people have the disease with its sever form that can last for several years or a lifelong disease. Serious joint damage can be caused as a result of this form of disease [3-12].

\section{Inflammatory Diseases in Humans}

Inflammation leads to several inflammatory diseases. It can cause over 100 diseases. Inflammatory diseases include Rheumatoid arthritis, Uveitis, Colitis, Appendicitis, Gastritis, Dermatitis, Nephritis, Hepatitis, Ankylosing Spondylitis, Peritonitis, and Dermatitis.

\section{Treatment of Inflammation}

There are many anti-inflammatory drugs. These drugs can treat inflammation and relief inflammatory symptoms [5].

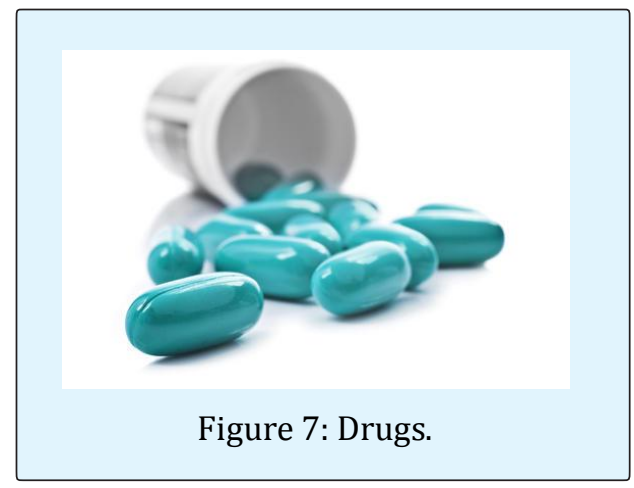

The anti-inflammatory drugs include many classes and categories of natural and synthetic agents that stop inflammation and prevent further damage that can caused by long standing inflammation by many mechanisms the most common anti-inflammatory drugs include steroidal and Non-Steroidal Anti-inflammatory drugs [7].

Both steroidal and non-steroidal anti-inflammatory drugs that act by inhibition of the production of some mediators such as pro-inflammatory prostaglandins (PGs) in this inhibition occurs in a variety of biological systems and also occurs in isolated tissues and cultured cells that put under appropriate incubation conditions[6]. Antiinflammatory drugs that treat inflammation and relief symptoms. The anti-inflammatory drugs include NonSteroidal Anti-inflammatory drugs, steroids, immune selective anti-inflammatory derivatives, anti histaminic drugs, cold and hot application.

NSAIDS prevent cells production of prostaglandin; damaged tissues release these chemicals causing swelling. They act as cyclooxygenase enzyme blockers thus reduce prostaglandins and thromboxane release.

To reduce side effects tablet and capsule should be taken with food to avoid side effects on GIT [15].

Non-steroidal Anti-Inflammatory Drugs (NSAIDs) have anti-inflammatory, antipyretic and analgesic effects. These effects occur by both the nonselective and selective cyclooxygenase (COX) inhibitors. The NSAIDs are widely and extensively used in the treatment of many inflammatory and painful conditions, including many inflammatory conditions such as rheumatic diseases. NSAIDs are very effective drugs in all inflammatory diseases and widely available as over-the-counter (OTC) formulations and in many prescription products [17].

NSAIDS prevent cells production of prostaglandin; injured tissues release these chemicals causing swelling. They act as cyclooxygenase enzyme (COX 2) blockers thus inhibit prostaglandins and thromboxane production. It can relieve arthritis symptoms. NSAIDS are rapidly acting drugs; within short time [5].

It's available in capsule, tablet, suppositories, injection, spray and cream. To reduce side effects tablet and capsule should be taken with food to avoid side effects on GIT [2]. Its common side effects which related to GIT are Nausea, vomiting, Heart burn, Loss of appetite, Diarrhea, Cramps and stomach pain, Kidney failure, Stroke and heart attack, Tinnitus, Dizziness and tiredness. There are other side effects which are rare they include Allergy and skin rash, and Breath shortness [5].

One of the most common drugs which used as antiinflammatory agents is Aspirin it is OTC drug used in treating inflammation and pain. It's salicylates prototype, cheap and most common, not induce sedation. Aspirin is non selective COX inhibitor that reduces prostaglandin synthesis and decrease receptor sensitivity to pain. Adverse effects of aspirin include Reye syndrome, GIT: 


\section{Virology \& Immunology Journal}

nausea and vomiting, Hypersensitivity and respiratory depressant [3].

Propionic acid derivative as Ibuprofen, ketoprofen, naproxen they are OTC or prescribed drug Analgesic, antipyretic and anti-inflammatory drugs. They are available at oral, rectal, injectable and local preparation.thy act by inhibition of cox reversibly. And thus reduce prostaglandin synthesis. Adverse effects of Propionic acid derivative include bleeding, GIT disturbance, Tinnitus and Dizziness [5-9].

\section{Natural Anti-Inflammatory Substances}

There are many natural agents and natural herpes that have anti-inflammatory effect. The discovery of certain natural agents that produce marked anti-inflammatory effects presents an opportunity for chiropractors and other natural health practitioners to add an important and effective adjunct to the management of these cases [7]. As such, a review of the physiological action and clinical studies, involving the use of proven natural antiinflammatory herbal agents, enables the patients to use these substances in a safe and responsible way, and thereby help patients eliminate or minimize their reliance upon more dangerous NSAIDs and other synthetic antiinflammatory drugs [2].

Some scientific and experimental researches had provided that there are many natural agents that have an efficient anti-inflammatory effect mainly due to the ability of these natural agents to modulate the enzymes activity or block 5-lipoxygenase and/or cyclooxygenase.

1. Ginger has many useful different uses such as spice, anti-inflammatory, diet. Ginger has gingerol that inhibits cyclooxygenase enzyme. Side-effects are little, but include heartburn and digestive upset. It should not be given to patients with renal problems [19].

2. Quercetin is a bioflavonoid compound that blocks the production of histamine and other anti-inflammatory enzymes.

3. Garlic is known as one of nature's amazing remedies for a variety of ailments, including preventing blood clots, lowering blood pressure and decreasing joint swelling and pain associated with arthritis [21].

4. Green tea is one of important nutrients that have antioxidants and anti-inflammatory action and support immune function and heart health.

5. Fish oil contain omega 3 that fight inflammation inside the body and reduce oxidative stress and inflammation.
So it better for public health to use fish or plant oil instead of oils come from animals [18].

\section{Materials and Methods}

\section{Chemicals}

Ginger pure powder form and Indomethacin were obtained from Sigma-Aldrich (USA). Carrageenan (1\%) and normal saline $(0.9 \%)$ were procured locally.

\section{Animals}

A total number of 24 female Albino rats weighing 150$250 \mathrm{~g}$ were divided into four groups each of them included6animals. The rats were kept in animal house of Department of Pharmacology and Toxicology, Faculty of pharmacy, October University for Modern Sciences and Arts (MSA) and housed in groups of six animals under environmentally controlled conditions(temperature $27 \pm 1^{\circ} \mathrm{C}$ and $12 \mathrm{hrs}$. light and dark cycles) with food (a standard pellet diet)and water ad libitum. The handling and use of animals were in accordance to the institutional ethical guidelines for animal care and use in scientific research.

\section{Experiment Design}

The rats under experiment were divided into four groups (each included 5 rats):

Group 1 (Placebo group): This group of rats was used as negative control group. The animals were subjected to intra-peritoneal injection with $1 \mathrm{ml}$ of the vehicle (normal saline).

Group 2 (Control positive group): The rats of this group were injected with $0.1 \mathrm{ml}$ of $1 \%$ freshly prepared suspension of carrageenan in normal saline viasupplanter route to induce local irritation and paw edema. This group didn't get any treatment.

Group 3 (Treated group using Indomethacin): This group was served as standard group in which the rats were injected with $1 \mathrm{ml}$ of the standard anti-inflammatory drug (Indomethacin) suspended in normal saline (in a dose rate of $25 \mathrm{mg} / \mathrm{kg}$ ) using intra-peritoneal routeone hour before induction of inflammation using carrageenan injection following the same conditions of group 2.

Group 4 (Treated group using Ginger extract): This group was considered the test group in which the rats were injected with $1 \mathrm{ml}$ of the Ginger suspended in normal saline (in a dose rate of $400 \mathrm{mg} / \mathrm{kg}$ ) using intra-peritoneal routeone hour before induction of inflammation using carrageenan injection following the same conditions of group 2. 


\section{Virology \& Immunology Journal}

\section{Rat Paw Volume Evaluations}

Rat paw volume was measured at regular selected time intervals $(1,2,4$, and $6 \mathrm{~h})$ after injection of carrageenan, using a plethysmograph. The edema rate and inhibition rate of each group were calculated as follows: Edema rate $(E)=\frac{V_{t}-V_{o}}{V_{o}}$, where $V_{o}$ and $V_{\mathrm{t}}$ were the volume before and after carrageenan injection $(\mathrm{mL})$ respectively. Inhibition $\operatorname{rate}(I)=\frac{E_{P}-E_{t}}{E_{P}}$, where $\mathrm{E}_{\mathrm{t}}$ and $\mathrm{E}_{\mathrm{p}}$ were the edema rate at $t$ hours after carrageenan injection $(\mathrm{mL})$ and the placebo group respectively.

\section{Results}

Effect of pre-injection of Indomethacin $25 \mathrm{mg} / \mathrm{kg}$ in control group or Ginger $400 \mathrm{mg} / \mathrm{kg}$ in treated group and these effects is studied on acute inflammation which is produced by injection of ginger $400 \mathrm{mg} / \mathrm{kg}$ IP and then after 1 hour sub-planter injection of $0.1 \mathrm{ml}$ carrageenan into the right hind paw and laboratory measuring of the blood serum contents of Tumor necrotic Factor (TNF- $\alpha$ ) and Interlukin-4 (IL-4) as well as Nitric Oxide (NO) these all are inflammatory mediators and cell mediated chemicals which is produced in high quantity during inflammation.

The laboratory results are given in Tables 1-3 and presented graphically in Figures 8-10.

In the First Group (the normal group) Which is injected by $1 \mathrm{ml}$ normal saline The Normal value of the blood serum contents of Tumor necrotic Factor (TNF- $\alpha$ ) is $26.7 \mathrm{Pg} / \mathrm{ml}$, Interlukin-4 (IL-4) is $87.4 \mathrm{Pg} / \mathrm{ml}$ and Nitric Oxide (NO) value is $19.8 \mu \mathrm{mol} / \mathrm{g}$ tissue.

In the second group (the control group) induction of inflammation is done by injection of carrageenan $0.1 \mathrm{ml}$ of $1 \%$ freshly prepared suspension of carrageenan in normal saline result in significant increase in the blood serum contents of (TNF- $\alpha$ ) from $26.7 \mathrm{Pg} / \mathrm{ml}$ to $111.3 \mathrm{Pg} / \mathrm{ml}$ and also result in significant increase in Nitric Oxide (NO) values from $19.8 \mu \mathrm{mol} / \mathrm{g}$ to $104.2 \mu \mathrm{mol} / \mathrm{g}$ tissue.

In the third group (Standard group) pre-injection of Indomethacin (25mg/kg; I.P.) 1 hour prior to carrageenan injection resulted in significant decrease in the blood serum contents of (TNF- $\alpha$ ) to $48.4 \mathrm{Pg} / \mathrm{ml}$ and also result in significant decrease in Nitric Oxide (NO) value to $42.7 \mu \mathrm{mol} / \mathrm{g}$ tissue.
In the Fourth group (Treated group) pre-injection of Ginger ( $400 \mathrm{mg} / \mathrm{kg}$; I.P.) 1 hour prior to carrageenan injection also result in significant decrease in the blood serum contents of (TNF- $\alpha$ ) to $40.9 \mathrm{Pg} / \mathrm{ml}$ and also result in significant decrease in Nitric Oxide (NO) value to 35.7 $\mu \mathrm{mol} / \mathrm{g}$ tissue.

\begin{tabular}{|c|c|c|c|c|c|c|}
\hline Code & & & TNF & & & \\
\hline Normal & 26.7 & 31.6 & 25.8 & 23.8 & 34.8 & $\mathbf{3 0 . 8}$ \\
\hline Control & 111.3 & 98.7 & 107 & 102 & 110 & $\mathbf{9 9 . 6}$ \\
\hline Ginger & 39.7 & 42.1 & 38.9 & 43.9 & 45.9 & $\mathbf{3 6 . 7}$ \\
\hline Indomethacin & 45.6 & 51.2 & 50.4 & 43.4 & 52.4 & $\mathbf{4 1 . 4}$ \\
\hline
\end{tabular}

Table 1: Values of serum contents of TNF- $\alpha$.

Normal value of the blood serum contents of Tumor necrotic Factor (TNF- $\alpha$ ) is $26.7 \mathrm{Pg} / \mathrm{ml}$, Interlukin-4 (IL-4) is $87.4 \mathrm{Pg} / \mathrm{ml}$ and Nitric Oxide (NO) value is $19.8 \mu \mathrm{mol} / \mathrm{g}$ tissue.

\begin{tabular}{|c|c|c|c|c|c|c|}
\hline Code & & & IL-4 & & & \\
\hline Normal & 74.6 & 87.4 & 79 & 84 & 76 & $\mathbf{7 4}$ \\
\hline Control & 15.4 & 12.3 & 10.85 & 17.85 & 11.85 & $\mathbf{1 8 . 5 7}$ \\
\hline Ginger & 50.1 & 41.1 & 43.6 & 41.3 & 48.3 & $\mathbf{5 0 . 6}$ \\
\hline Indomethacin & 39.4 & 37.8 & 36.6 & 34.3 & 43.5 & $\mathbf{4 2 . 4}$ \\
\hline
\end{tabular}

Table 2: Values of serum contents of IL-4.

Induction of inflammation is done by injection of carrageenan $0.1 \mathrm{ml}$ of $1 \%$ freshly prepared suspension of carrageenan in normal saline result in significant increase in the blood serum contents of (TNF- $\alpha$ ) from $26.7 \mathrm{Pg} / \mathrm{ml}$ to $111.3 \mathrm{Pg} / \mathrm{ml}$ and also result in significant increase in Nitric Oxide (NO) values from $19.8 \mu \mathrm{mol} / \mathrm{g}$ to 104.2 $\mu \mathrm{mol} / \mathrm{g}$ tissue.

\begin{tabular}{|c|c|c|c|c|c|c|}
\hline Code & & & NO & & & \\
\hline Normal & 23.4 & 19.8 & 19.6 & 17.3 & 24.6 & $\mathbf{2 7 . 5}$ \\
\hline Control & 89.6 & 104.2 & 94.9 & 99.8 & 102.9 & $\mathbf{1 0 1 . 9}$ \\
\hline Ginger & 37.8 & 33.7 & 33.75 & 31.7 & 38.6 & $\mathbf{4 0 . 5}$ \\
\hline Indomethacin & 45.7 & 39.7 & 40.7 & 38.7 & 45.7 & $\mathbf{4 7 . 2}$ \\
\hline
\end{tabular}

Table 3: Values of serum contents of Nitric oxide NO.

Pre-injection of Indomethacin (25mg/kg; I.P.) 1 hour prior to carrageenan injection resulted in significant decrease in the blood serum contents of (TNF- $\alpha$ ) to 48.4 $\mathrm{Pg} / \mathrm{ml}$ and also result in significant decrease in Nitric Oxide (NO) value to $42.7 \mu \mathrm{mol} / \mathrm{g}$ tissue. 
Pre-injection of Ginger (400 mg/kg; I.P.) 1 hour prior to carrageenan injection also result in significant decrease in the blood serum contents of (TNF- $\alpha$ ) to $40.9 \mathrm{Pg} / \mathrm{ml}$ and

\section{Virology \& Immunology Journal}

also result in significant decrease in Nitric Oxide (NO) value to $35.7 \mu \mathrm{mol} / \mathrm{g}$ tissue.

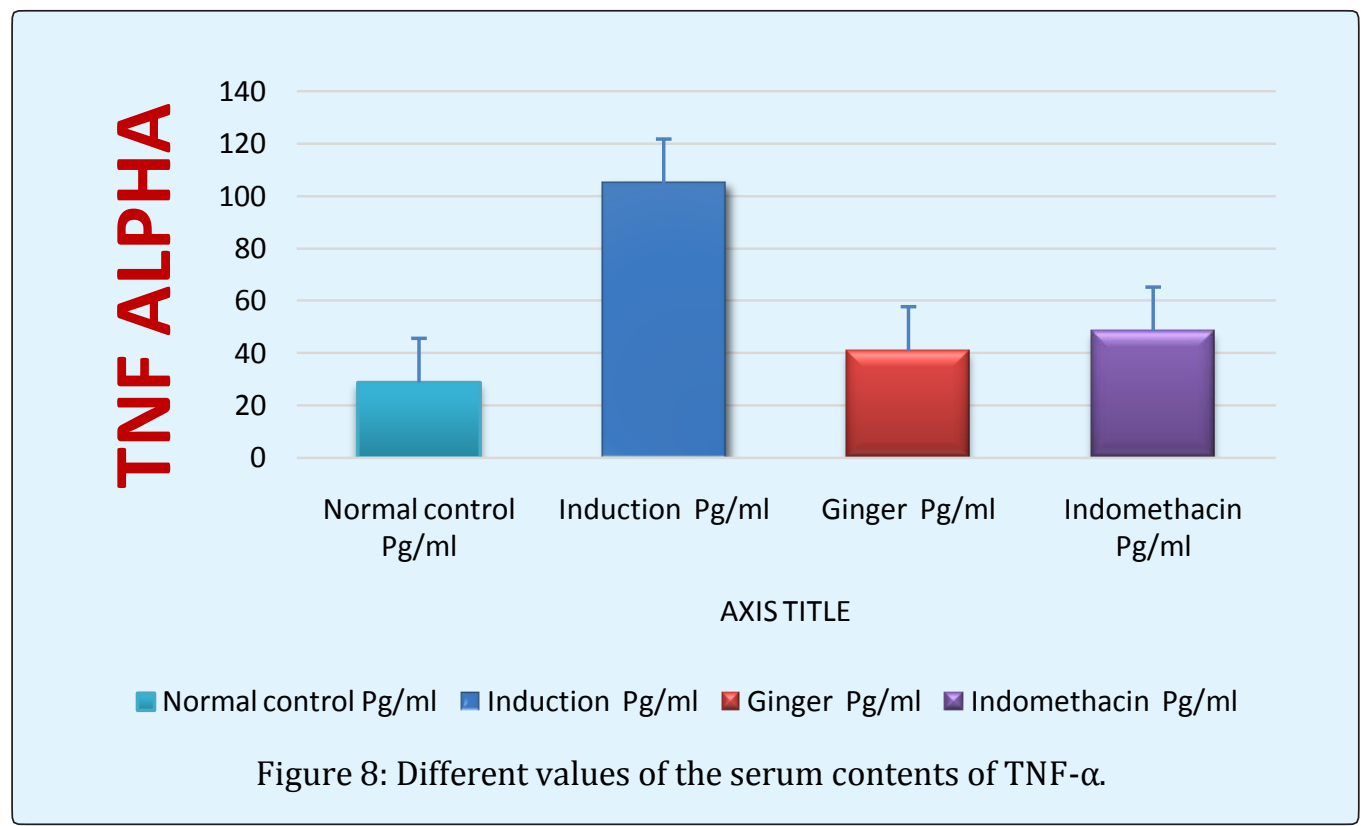

Normal value of the blood serum contents of Tumor necrotic Factor (TNF- $\alpha$ ) is $26.7 \mathrm{Pg} / \mathrm{ml}$. Injection of carrageenan show significant increase in the blood serum contents of (TNF- $\alpha$ ) from $26.7 \mathrm{Pg} / \mathrm{ml}$ to $111.3 \mathrm{Pg} / \mathrm{ml}$.
Injection of Indomethacin (25mg/kg; I.P.) 1 hour prior to carrageenan injection resulted in significant decrease in the blood serum contents of (TNF- $\alpha$ ) to $48.4 \mathrm{Pg} / \mathrm{ml}$ and also Injection of Ginger ( $400 \mathrm{mg} / \mathrm{kg}$; I.P.) 1 hour prior to carrageenan injection also result in significant decrease in the blood serum contents of (TNF- $\alpha$ ) to $40.9 \mathrm{Pg} / \mathrm{ml}$.

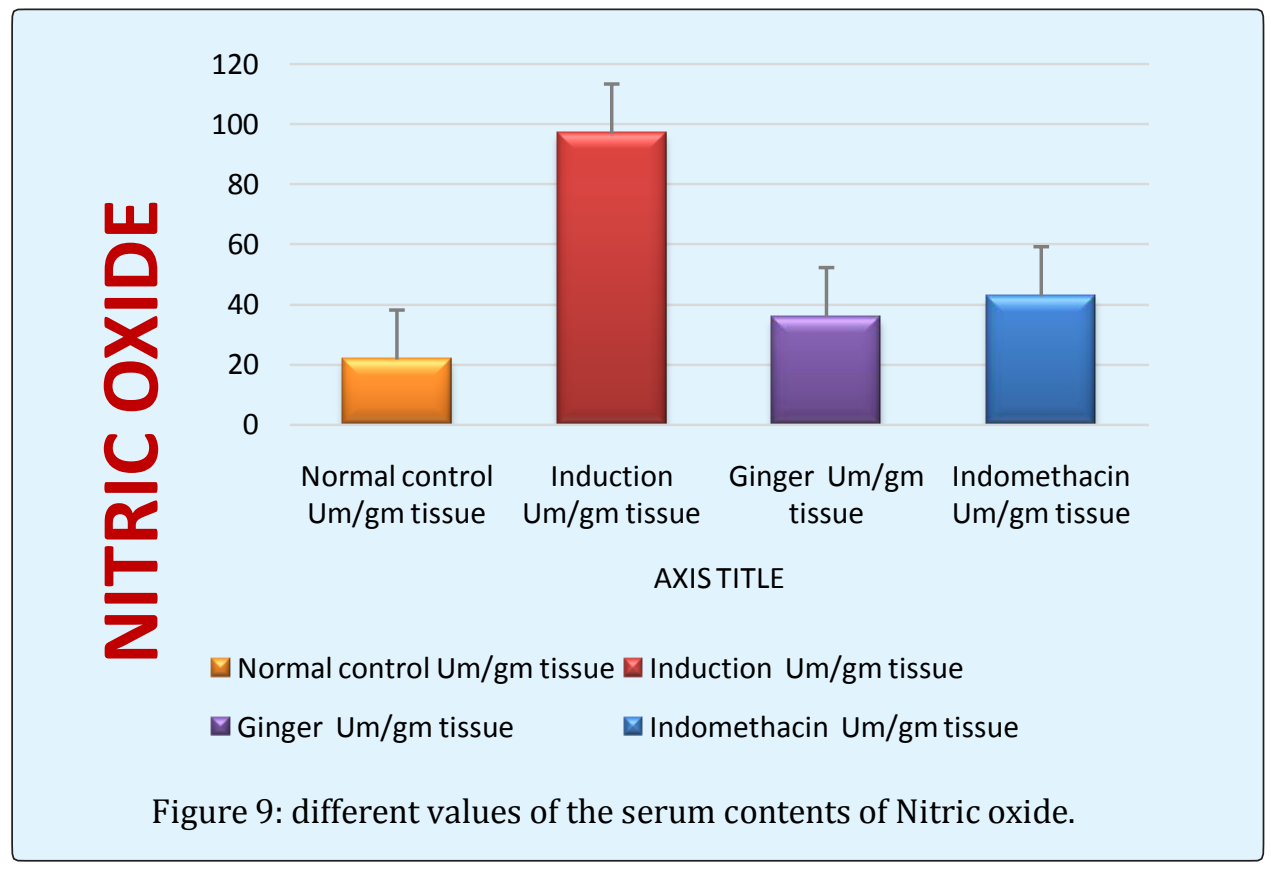

Sameh S Gad. Effect of Ginger as Anti-Inflammatory Agent on Serum Nitric Oxide, Tumor Necrotic Factor $\alpha$ (TNF- $\alpha$ ) and Interleukin 4 (IL-4) in Albino Rats with Carrageenan Induced Paw Edema. 
Normal value of the blood serum contents of Nitric Oxide (NO) is $19.8 \mu \mathrm{mol} / \mathrm{g}$ tissues.

Induction of inflammation by carrageenan result in significant increase in the blood serum contents of in Nitric Oxide (NO) values from $19.8 \mu \mathrm{mol} / \mathrm{g}$ to 104.2 $\mu \mathrm{mol} / \mathrm{g}$ tissue.

\section{Virology \& Immunology Journal}

Indomethacin $(25 \mathrm{mg} / \mathrm{kg}$; I.P.) 1 hour prior to carrageenan injection resulted in significant decrease in the blood serum contents of Nitric Oxide (NO) value to $42.7 \mu \mathrm{mol} / \mathrm{g}$ tissue.

injection of Ginger ( $400 \mathrm{mg} / \mathrm{kg}$; I.P.) 1 hour prior to carrageenan injection also result in significant decrease in the blood serum contents of Nitric Oxide (NO) value to $35.7 \mu \mathrm{mol} / \mathrm{g}$ tissue.

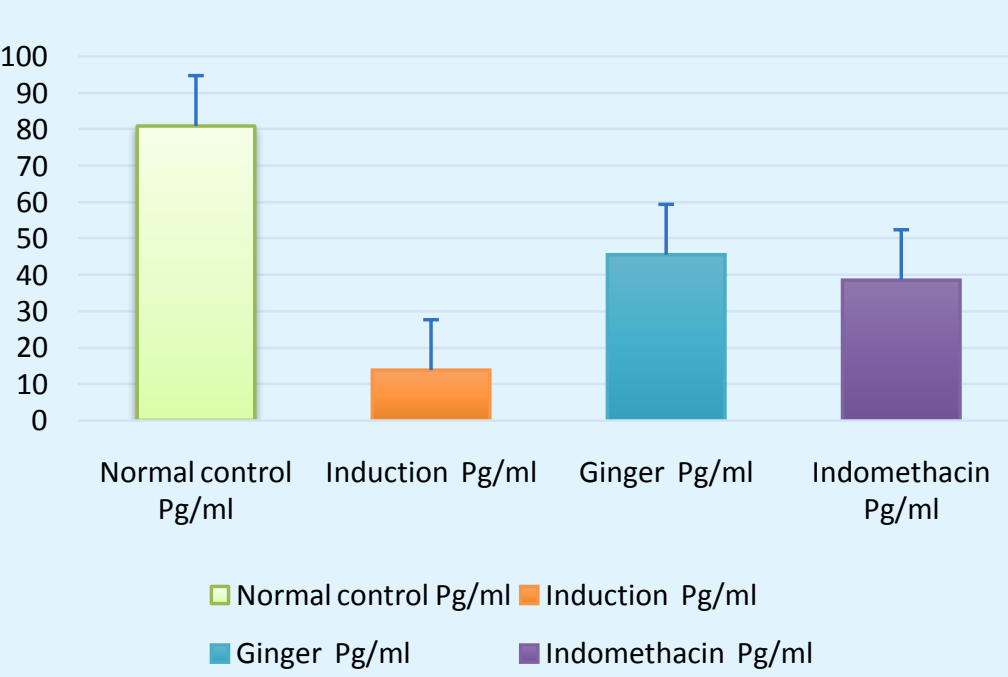

Figure 10: show the different values of the blood serum contents of IL-4.

Edema test also done to measure the difference in water displacement caused by different groups.

Tests done to compare the statistical significant changes between controls, Carrageenan induced paw edema, Indomethacin prophylaxis rats and with ginger extract treatment.

Edema results are given in Tables 4,6-8 and presented graphically in Figures 10-13.

\begin{tabular}{|c|c|c|}
\hline & Before injection & After \\
\hline Rat 1 & $1 \mathrm{ml}$ & $1 \mathrm{ml}$ \\
\hline Rat 2 & $1 \mathrm{ml}$ & $1 \mathrm{ml}$ \\
\hline Rat 3 & $0.9 \mathrm{ml}$ & $1 \mathrm{ml}$ \\
\hline Rat 4 & $1 \mathrm{ml}$ & $1 \mathrm{ml}$ \\
\hline Rat 5 & $1 \mathrm{ml}$ & $1 \mathrm{ml}$ \\
\hline Rat 6 & $1 \mathrm{ml}$ & $1 \mathrm{ml}$ \\
\hline
\end{tabular}

Table 4: Edema reading in normal group (Group 1).
In this group which serves as negative control group and is injected with normal saline $1 \mathrm{ml}$ IP the Normal value of oedema water displacement ranging from 0.9-1.1 $\mathrm{ml}$. There is no significant difference between water displacement caused by normal group before and after injection of normal saline.

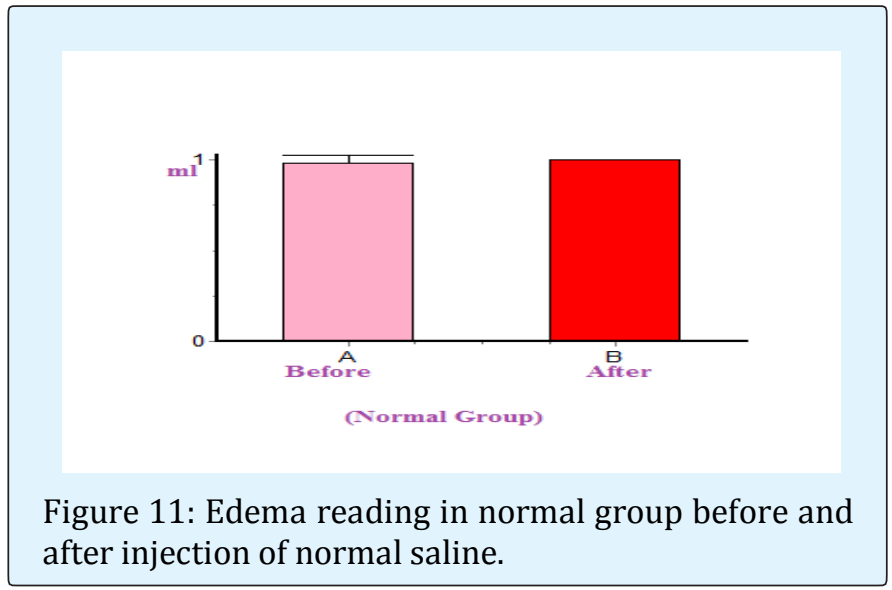

Sameh S Gad. Effect of Ginger as Anti-Inflammatory Agent on Serum Nitric Oxide, Tumor Necrotic Factor $\alpha$ (TNF- $\alpha$ ) and Interleukin 4 (IL-4) in Albino Rats with Carrageenan Induced Paw Edema. 


\section{Virology \& Immunology Journal}

\begin{tabular}{|c|c|c|}
\hline & Before injection & After \\
\hline Rat 1 & $1 \mathrm{ml}$ & $2 \mathrm{ml}$ \\
\hline Rat 2 & $1 \mathrm{ml}$ & $2.2 \mathrm{ml}$ \\
\hline Rat 3 & $0.9 \mathrm{ml}$ & $2 \mathrm{ml}$ \\
\hline Rat 4 & $1 \mathrm{ml}$ & $1.8 \mathrm{ml}$ \\
\hline Rat 5 & $1.1 \mathrm{ml}$ & $1.6 \mathrm{ml}$ \\
\hline Rat 6 & $1 \mathrm{ml}$ & $2 \mathrm{ml}$ \\
\hline
\end{tabular}

Table 5: Edema reading in carrageenan group (Group 2).

In the group 2 there is induction of inflammation using $0.1 \mathrm{ml}$ of freshly prepared suspension of carrageenan into the right hind paw which causes edema and inflammation this inflammation is measured by water displacement which is increased significantly in group injected with carrageenan.

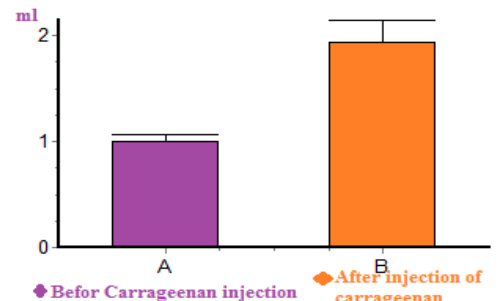

Figure 12: Edema reading in control group before and after injection of Carrageenan.

\begin{tabular}{|c|c|c|}
\hline & $\begin{array}{c}\text { Before injection } \\
\text { (Indomethacin 25 mg/kg) }\end{array}$ & After \\
\hline Rat 1 & $1 \mathrm{ml}$ & $1.5 \mathrm{ml}$ \\
\hline Rat 2 & $1 \mathrm{ml}$ & $1.3 \mathrm{ml}$ \\
\hline Rat 3 & $0.9 \mathrm{ml}$ & $1.2 \mathrm{ml}$ \\
\hline Rat 4 & $1 \mathrm{ml}$ & $1 \mathrm{ml}$ \\
\hline Rat 5 & $1.1 \mathrm{ml}$ & $1 \mathrm{ml}$ \\
\hline Rat 6 & $1 \mathrm{ml}$ & $1 \mathrm{ml}$ \\
\hline
\end{tabular}

Table 6: Edema reading in Indomethacin + Carrageenan (Group 3).

In the group 3 Indomethacin $(25 \mathrm{mg} / \mathrm{kg}$; I.P.) 1 hour prior to carrageenan injection and then induction of inflammation using $0.1 \mathrm{ml}$ of freshly prepared suspension of carrageenan into the right hind paw which resulted in decrease in inflammation and oedema caused by carrageenan generally due to Indomethacin [7-12].

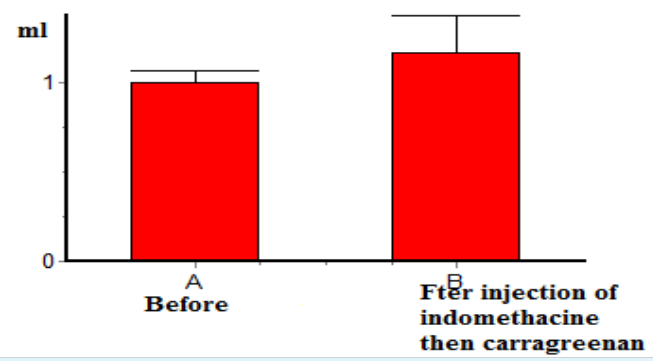

Figure 13: Edema reading in group 3 before and after injection of Indomethacin then Carrageenan.

\begin{tabular}{|c|c|c|}
\hline & Before injection & After \\
\hline Rat 1 & $1 \mathrm{ml}$ & $1.5 \mathrm{ml}$ \\
\hline Rat 2 & $1 \mathrm{ml}$ & $2 \mathrm{ml}$ \\
\hline Rat 3 & $1 \mathrm{ml}$ & $1.1 \mathrm{ml}$ \\
\hline Rat 4 & $0.9 \mathrm{ml}$ & $1.3 \mathrm{ml}$ \\
\hline Rat 5 & $0.8 \mathrm{ml}$ & $1.2 \mathrm{ml}$ \\
\hline Rat 6 & $1.1 \mathrm{ml}$ & $1.2 \mathrm{ml}$ \\
\hline
\end{tabular}

Table 7: Edema reading in Ginger+ Carrageenan (Group4).

In the group 4 pre-injection of Ginger ( $400 \mathrm{mg} / \mathrm{kg}$; I.P.) 1 hour prior to carrageenan injection also result in significant decrease in oedema produced by carrageenan [5-7].

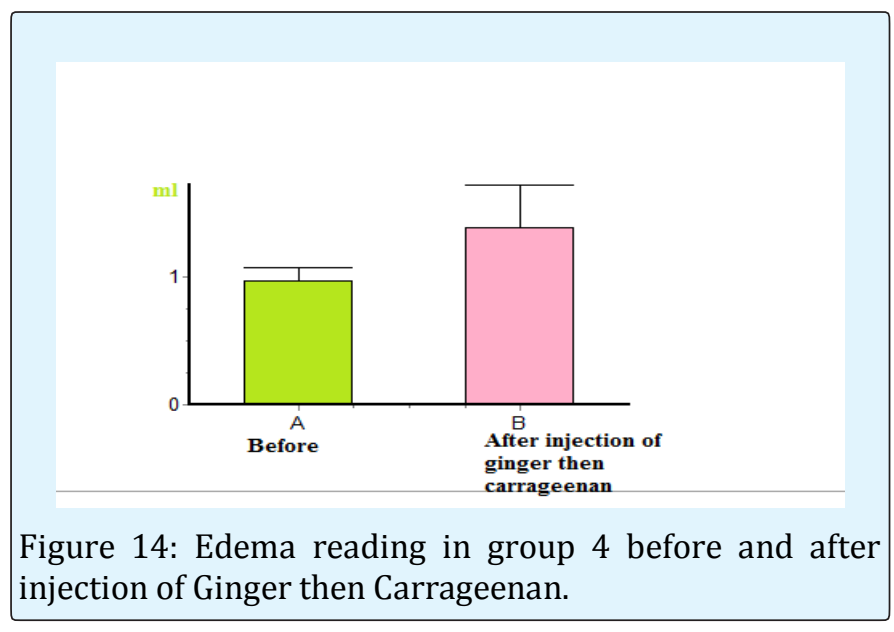




\section{Virology \& Immunology Journal}

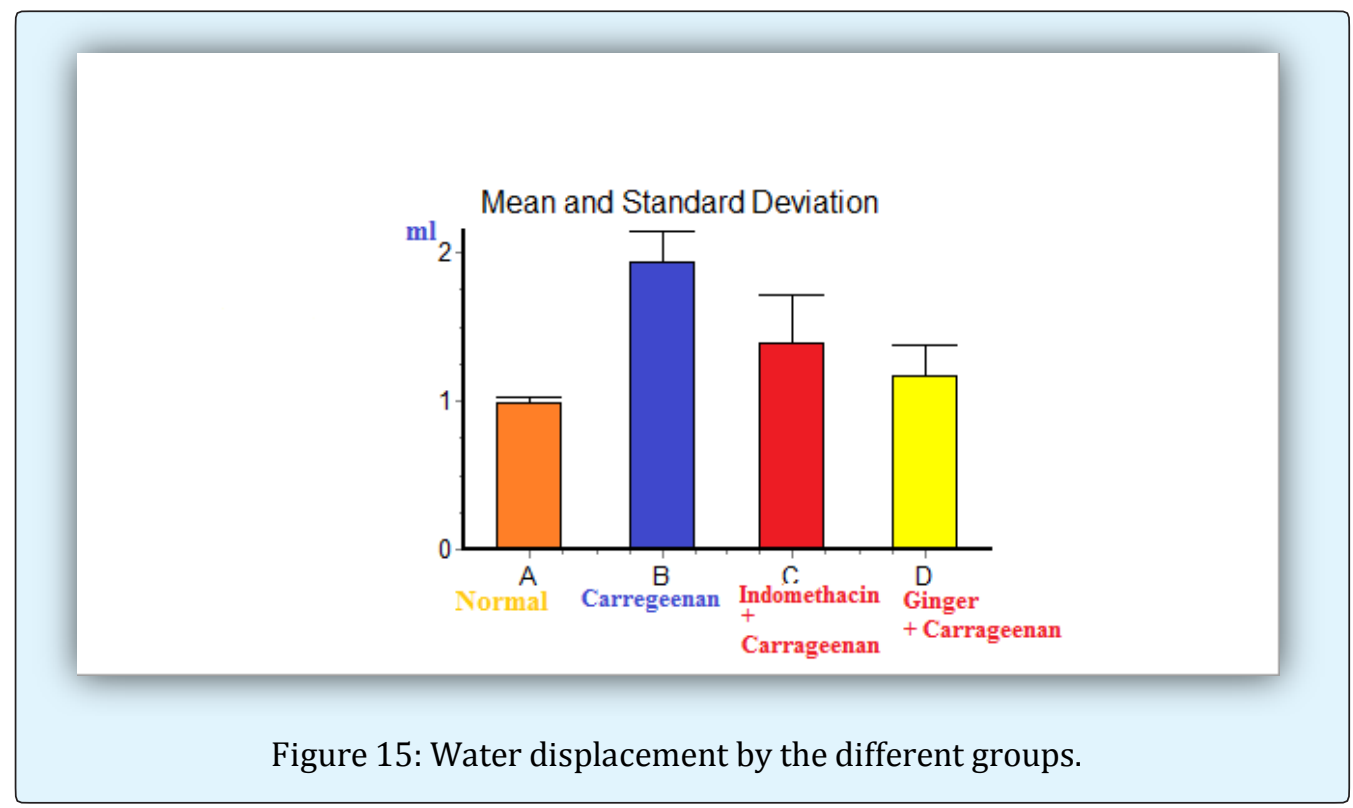

Water displacement of the right hind paw is normal in the group 1 (normal group) which receive normal saline and the values are ranging from 0.9 to $1.2 \mathrm{ml}$. While the induction of inflammation result in inflammation and significant increase in the paw edema and hence increase in water displacement ranging from 1.6 to $2.2 \mathrm{ml}$.

\section{Statistical Analysis}

Results are expressed as $\mathrm{x} \pm \mathrm{s}$. Statistical evaluations were made using ANOVA or Student's-test, and values were considered significantly different when $\mathrm{P}<0.05$.

\section{Discussion}

Paw edema induced by carrageenan in animal models is a suitable test that is used for evaluating drugs and agents that has anti-inflammatory activity, this method has frequently been used to assess the antiedematous effect of the drug. Carrageenan is a strong chemical use for the release of inflammatory and proinflammatory mediators (prostaglandins, leukotrienes, histamine, bradykinin, TNF- $\alpha$, etc.) [1-3].

Injection of $0.1 \mathrm{ml}$ of freshly prepared $1 \%$ suspension of carrageenan in the Rats right hind paw causes inflammation an early inflammatory response that lasts 6 $\mathrm{h}$ and a second late response that peaks at $72 \mathrm{~h}$, declining at $96 \mathrm{~h} \mathrm{[5-8].}$
Ginger will be administered in aqueous solution 200 $\mathrm{mg} \backslash \mathrm{kg}$ Indomethacin as $25 \mathrm{mg} \backslash \mathrm{kg}$. Inflammation is a complex response. There are circulatory changes in the inflammatory response these changes involve changes in permeability of the walls of vessels, white blood cells response and Release of different soluble mediators these circulatory changes also known as hemodynamic changes. It is the first response from the body to injury or mechanical stimulus which causes stimulation of the nerves that transmit the signals to the cells of smooth muscles that found in precapillary arterioles this result in edema [4-8].

The purpose of our research project is to calculate, evaluate and compare the anti-inflammatory activity of extract of (ginger) in animal model with acute inflammation in experimental design with Indomethacin as standard anti-inflammatory drug. Aqueous extract of $(200 \mathrm{mg} / \mathrm{kg}$ will be administered to the test group of rats then paw volume will be measured by a plethysmometer and compared with the control group. Indomethacin and ginger $200 \mathrm{mg} / \mathrm{kg}$ displayed inhibition of paw edema. In the anti-inflammatory effect of ginger and Indomethacin, and furthermore an enhanced as ginger root showed significant anti-inflammatory activity in the model studied, it can be investigated further as a promising antiinflammatory agent [4-7].

In many previous studies, the results showed that there is significant anti-inflammatory activity of the 


\section{Virology \& Immunology Journal}

ginger root extract possessed when administered to animals with inflammation. The efficacy for reducing paw oedema induced by carrageenan. Inhibition of carrageenan-induced inflammation in rats has gained popularity as a test procedure to screen antiinflammatory agents. The development of carrageenaninduced oedema is bi-phasic [4].

Anti-inflammatory and activity comparable to that of the standard drug Indomethacin in the model of carrageenan-induced rat paw oedema, and on coadministration marginally improved the antiinflammatory profile of Indomethacin. Ginger antiinflammatory activity could be guessed to be due to an inhibitory effect of mediators of inflammation such as Histamine, serotonin, kinins and other cytokines that can be found in the inflammatory process. Ginger extract of ginger roots can combined with other drugs such as Indomethacin as ginger can show a significant antiinflammatory effect of ginger root extract along with gastro-protective effects could warrant the coadministration of it along with NSAIDs [2-6].

Induction of Inflammation in animals:

Carrageenan induced paw edema:

This method aims to detect the possible inflammatory action of compounds in rats

Animal preparation: house (150-250gm) female albino rats providing water and food Each rat should be weighing Select rats randomly for single doses of compound and vehicle. Evaluation of carrageenan:

Adjust the dose of $0.1 \mathrm{ml}$ for sub planter injection after dissolving carrageenan in the vehicle.

Paw volume is measured

Induce edema by injection of $0.1 \mathrm{ml}$ carrageenan and then measure the hind paw

Determine the volume after injection to the volume before ratio.

Measure the parameters in serum like NO, IL-4 and TNF$\alpha$.

In the third group (Standard group) pre-injection of Indomethacin (25mg/kg; I.P.) 1 hour prior to carrageenan injection resulted in significant decrease in the blood serum contents of (TNF- $\alpha$ ) to $48.4 \mathrm{Pg} / \mathrm{ml}$ and also result in significant decrease in Nitric Oxide (NO) value to $42.7 \mu \mathrm{mol} / \mathrm{g}$ tissue.

Animal preparation: house (150-250gm) female albino rats providing water and food each rat should be weighing Select rats randomly for single doses of compound and vehicle. Make prophylaxis by administration of Indomethacin: This group was injected by Indomethacin $25 \mathrm{mg} / \mathrm{kg}$. Paw volume is measured. Evaluation of carrageenan [17].

One hour later, adjust the dose of $0.1 \mathrm{ml}$ for sub planter injection after dissolving carrageenan in the vehicle.

Induce edema by injection of $0.1 \mathrm{ml}$ carrageenan and then measure the hind paw.

Determine the volume after injection to the volume before ratio.

Measure the parameters in serum like NO, IL-4 and TNF$\alpha$.

In the Fourth group (Treated group) pre-injection of Ginger (400 mg/kg; I.P.) 1 hour prior to carrageenan injection also result in significant decrease in the blood serum contents of (TNF- $\alpha$ ) to $40.9 \mathrm{Pg} / \mathrm{ml}$ and also result in significant decrease in Nitric Oxide (NO) value to 35.7 $\mu \mathrm{mol} / \mathrm{g}$ tissue [18-31].

Evaluation of carrageenan:

Adjust the dose of $0.1 \mathrm{ml}$ for sub planter injection after dissolving carrageenan in the vehicle.

Paw volume is measured

Induce edema by injection of $0.1 \mathrm{ml}$ carrageenan and then measure the hind paw

Determine the volume after injection to the volume before ratio.

Measure the parameters in serum like NO, IL-4 and TNF- $\alpha$ Evaluation of ginger:

One hour later, this group is injected by $0.1 \mathrm{ml}$ of ginger.

Paw volume is measured

Measure the parameters in serum like NO, IL-4 and TNF- $\alpha$

This study come to an agreement with earlier reports which showed that (6)-shogaol isolated from ginger extract inhibited experimentally- induced swelling of the hind paw in rats. This, they reported may be due to the ability of ginger to inhibit NO, TNF $\alpha$ and IL-4. [19-25]

Our study revealed that the ginger can inhibit carrageenan- induced edema in rats. This study may help in expecting the importance of anti-inflammatory agents that act by decreasing or preventing the release of mediators of acute inflammation [12-14]. Induction of inflammation by Carrageenan was performed on 24 rats of both sexes weighing (150-250 g).

As well as, steroids have good anti- inflammatory action but should be taken under supervisor to establish therapeutic dose according to weight and age because steroids have dangerous side effects such as renal failure, lung disease, and central nervous system depression 


\section{Virology \& Immunology Journal}

leading to coma. Most important examples of steroids in the market dexamethasone, prednisolone but this group should be taken by recommendation of doctor. It must not stop prednisolone suddenly because it will cause many adverse effects like osteoporosis, increase in blood pressure, disorder in growth in childhood, abnormal hair growth of all the body. So you should ask advice from the doctors for dose because it depends on age, weight, and health state [11-20].

Injection of $0.1 \mathrm{ml}$ of freshly prepared $1 \%$ suspension of carrageenan in the Rats right hind paw causes inflammation an early inflammatory response that lasts 6 $\mathrm{h}$ and a second late response that peaks at $72 \mathrm{~h}$, declining at $96 \mathrm{~h} \mathrm{[5-8].}$

Ginger will be administered in aqueous solution 200 $\mathrm{mg} \backslash \mathrm{kg}$ Indomethacin as $25 \mathrm{mg} \backslash \mathrm{kg}$. Inflammation is a complex response. There are circulatory changes in the inflammatory response these changes involve changes in permeability of the walls of vessels, white blood cells response and Release of different soluble mediators these circulatory changes also known as hemodynamic changes. It is the first response from the body to injury or mechanical stimulus which causes stimulation of the nerves that transmit the signals to the cells of smooth muscles that found in precapillary arterioles this result in edema [4-8].

\section{Conclusion}

This study has shown that ginger proved a significant anti-oedematogenic and anti-inflammatory activity on hind paw edema induced by carrageenan. Since carrageenan-induced inflammation model is a significant prognostic test for anti-inflammatory agents acting by the mediators of acute inflammation. The results of this study are an indication that ginger can be effective in acute inflammatory disorders. The anti-inflammatory effect of Ginger is near to the anti-inflammatory effect of the NonSteroidal Anti-inflammatory agent Indomethacin [31].

As ginger showed significant anti-inflammatory activity in the model studied, it can be investigated further as a promising anti-inflammatory agent to be a natural agent treating inflammation and avoid side effects which caused by synthetic agents [12-15].

\section{References}

1. Murray M (2014) The Healing Power of Herbs. Prima Publishing. Rocklin, CA.
2. Hayliyar J, Macpherson A, Bjarnason I (2012) et al. Gastro protection and nonsteroidal anti-inflammatory drugs. Drug Safety 7(2): 86-105.

3. Anadin ibuprofen $200 \mathrm{mg}$ tablets (2011) Surrey, England: Electronic Medicines Compendium.

4. Altenburg SP, Martins MA, Silva AR, Cordeiro RS, Castro-Faria-Neto HC (2011) LPS-induced blood neutrophilia is inhibited by alpha 1-adrenoceptor antagonists: a role for catecholamines. J Leukoc Biol 61(6): 689-694.

5. Wilson SJ, Roche AM, Kostetskaia E, Smyth EM (2004) Dimerization of the human receptors for prostacyclin and thromboxane facilitates thromboxane receptormediated cAMP generation. J Biol Chem 279(51): 53036-53047.

6. Breyer RM, Bagdassarian CK, Myers SA, Breyer MD (2010) Prostanoid receptors: Subtypes and signaling. Annu Rev Pharmacol Toxicol 41: 661-690.

7. Smith WL, DeWitt DL, Garavito RM (2013) Cyclooxygenases: Structural, cellular, and molecular biology. Annu Rev Biochem 69: 145-182.

8. Libby P, Ridker PM, Maseri A (2002) Inflammation and atherosclerosis. Circulation 105(9): 1135-1143.

9. Locati M, Murphy PM (1999) Chemokines and chemokine receptors: biology and clinical relevance in inflammation and AIDS. Annu Rev Med 50: 425440.

10. Maes M, Lin Ah, Delmeire L, Van Gastel A, Kenis G, et al. (2014) Elevated serum interleukin-6 (IL-6) and IL6 receptor concentrations in posttraumatic stress disorder following accidental man-made traumatic events. Biol Psychiatry 45(7): 833-839.

11. Maes M, Meltzer HY, Bosmans E, Bergmans R, Vandoolaeghe E, et al. (2014) Increased plasma concentrations of interleukin-6, soluble interleukin-6, soluble interleukin-2 and transferrin receptor in major depression. J Affect Disord 34(4): 301-309.

12. Martin JHJ, Crotty S, Warren P, Nelson PN (2007) Does an apple a day keep the doctor away because a phytoestrogen a day keeps the virus at bay? A review of the anti-viral properties of phytoestrogens. Phytochemistry 68(3): 266-274. 
13. Maes M, Van Bockstaele DR, Van Gastel A, Song C, Schotte C, et al. (2014) The effects of psychological stress on leukocyte subset distribution in humans: evidence of immune activation. Neuropsychobiology 39(1): 1-9..

14. Masika PJ, Van Averbeke W, Sonandi A (2011) Use of herbal remedies by small scale farmers to treat livestock diseases in the central Eastern Cape Province, South Africa. J S Afr Vet Ass 71(2): 87- 91.

15. O’Byrne KJ, Dalgleish AG (2001) Chronic immune activation and inflammation as the cause of malignancy. Br J Cancer 85(4): 473-483.

16. O’Byrne KJ, Dalgleish AG, Browning MJ, Steward WP, Harris AL (2000) The relationship between angiogenesis and the immune response in carcinogenesis and the progression of malignant disease.. Eur J Cancer 36(2): 151-169.

17. Rudd PT, Carrington D (1985) A prospective study of chlamydial, mycoplasmal and viral infections in a neonatal intensive care unit. Arch Dis Child 59(2): 120-125.

18. Taylor-Robinson D, Furr PM, Liberman MM (1984) The occurrence of genital mycoplasmas in babies with and without respiratory diseases. Acta Paediatrica 73(3): 383-386.

19. Rudd PT, Cassell GH, Waites KB, Davis JK, Duffy LB (1989) Ureaplasma urealyticum pneumonia: experimental production and demonstration of agerelated susceptibility. Infect Immun 57(3): 918-925.

20. Crouse DT, Odrezin GT, Cutter GR, Reese JM, Hamrick WB, et al. (1993) Radiographic changes associated with tracheal isolation of Ureaplasma urealyticum from neonates. Clin Infect Dis 17(1): S122-130.

21. Podolsky DK (1991) Inflammatory bowel disease (1). N Engl J Med 325(13): 928-937.

22. Rifai N, Ridker PM (2002) Inflammatory markers and coronary heart disease. Curr Opin Lipidol 13(4): 383 389.

\section{Virology \& Immunology Journal}

23. Ross R (2011) Atherosclerosis: current understanding of mechanisms and future strategies in therapy. Transplant Proc 25(2): 2041-2043.

24. Middleton E, Kandaswami C, Theoharides TC (2000) The Effects of Plant Flavonoids on Mammalian Cells: Implications for Inflammation, Heart Disease, and Cancer. Pharmacol Rev 52(4): 673-751.

25. Metzger WJ, Page CP (2015) Biology of Platelets, in Allergy: Principles and Practice. Pp: 99-117

26. Gupta S, Leatham EW, Carrington D, Mendall MA, Kaski JC, et al. (1997) Elevated Chlamydia pneumoniae antibodies, cardiovascular events, and azithromycin in male survivors of myocardial infarction. Circulation 96: 404-407.

27. Rubio-Perez JM, Morillas-Ruiz JM (2012) A review: Inflammatory processin Alzheimer disease, Role of Cytokines. The scientific world journal 2012: 756357.

28. Sziksz E, Pap D, Lippai R, Béres NJ, Fekete A, et al. (2015) Fibrosis related inflammatory mediators: role of the IL-10 cytokines family. Hindawi publishing corporation pp: 1-15.

29. Farahpour M, Khoshgozaran I (2015) Antinosiceptive and anti-inflammatory activities of hydroethanolic extract of urtica diocica. International journal of biology 4(1): 160-170.

30. Yao L, Kan EM, Lu J, Hao A, Dheen ST, et al. (2013) Toll-like receptor 4 mediates microglial activation and production of inflammatory mediators in neonatal rat brain following hypoxia: role of TLR4 in hypoxic microglia. Journal of Neuroinflammation 10: 23.

31. Garcia FA, Rebouças JF, Balbino TQ, da Silva TG, de Carvalho-Júnior $\mathrm{CH}$, et al. (2015) Pentoxifylline reduces inflammatory process in diabetic rats: relationship with decrease of pro-inflammatory cytokines and inducible nitric oxide synthase. Journal of inflammation 12: 33.

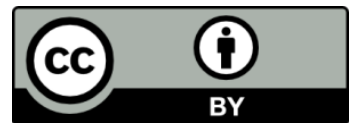

Sameh S Gad. Effect of Ginger as Anti-Inflammatory Agent on Serum Nitric Oxide, Tumor Necrotic Factor $\alpha$ (TNF- $\alpha$ ) and Interleukin 4 (IL-4) in Albino Rats with Carrageenan Induced Paw Edema. Virol Immunol J 2018, 2(8): 000179. 